Studia nad Autorytaryzmem i Totalitaryzmem 40, nr 4 Wrocław 2018

DOI: $10.19195 / 2300-7249.40 .4 .3$

\author{
SEBASTIAN FIKUS \\ ORCID: 0000-0002-1155-2762 \\ Uniwersytet Śląski w Katowicach
}

\title{
Obozy koncentracyjne jako nowoczesna forma zwalczania przestępczości w Republice Federalnej Niemiec?
}

W Ministerstwie Sprawiedliwości Kraju Związkowego Nadrenii-Westfalii w Düsseldorfie 5 kwietnia 1954 roku odbyła się narada oficerów policji i kierowników wydziałów kryminalnych tego landu. Jej tematem były metody zwalczania przestępczości w ówczesnej Republice Federalnej. Pokłosiem tego spotkania było pismo Krajowego Ministra Prawa dra Rudolfa Amelunxena do ówczesnego Federalnego Ministra Sprawiedliwości Fritza Neumayera (FDP) w Bonn. Dokument ten został wysłany również do innych krajowych ministrów sprawiedliwości ówczesnej Republiki Federalnej ${ }^{1}$. Czytamy w nim:

Zdaniem zgromadzonych urzędników ${ }^{2}$ konieczna jest pilna reorganizacja systemu kontroli policyjnej i stworzenie nowego, skutecznego środka zapobiegania przestępczości. Za znakomity przykład takiego instrumentu urzędnicy uważają rozporządzenie Pruskiego Ministra Spraw Wewnętrznych z 14.12.1937 roku [sic!]. Dokument ten wprowadził nowe reguły organizacji kontroli społeczeństwa przez policję. Wprowadzone wówczas środki doprowadziły do natychmiastowego, bardzo poważnego spadku [schlagartige Verminderung] przestępczości [...]. Korzystając z tych doświadczeń, wydaje się wskazane, żeby zarządzeniu pruskiego ministra z dnia 14.12.1937 roku nadać ponownie moc prawną. Oparcie na nim kontroli policyjnej stworzyłoby skuteczne ramy gwarantujące publiczne bezpieczeństwo [...]. Zastosowanie określonych w rozporządzeniu działań prewencyjnych spowodowałoby również dzisiaj gwałtowny spadek przestępczości. Trzeba stworzyć system prewencyjnych reguł umożliwiających osadzenie potencjalnych przestępców w więzieniach na mocy wyroku sądowego. Jeszcze

${ }^{1}$ Federalne Archiwum w Koblencji - Bundesarchiv Koblenz (dalej: BAK), Zespół/Bestand (B) 106, nr akt 15738, pismo ministra Prawa Kraju Nadrenii-Westfalii (Nordrhein-Westfalen) z 12 kwietnia 1954 roku o sygnaturze 4350-III A. 3. Jeśli nie podano inaczej, thum. S.F.

${ }^{2}$ W systemie Republiki Federalnej oficerowie policji nie są funkcjonariuszami, tylko urzędnikami. 
skuteczniejszym instrumentem działań prewencyjnych byłaby możliwość zamykania potencjalnych przestępców w Domach Pracy [Arbeitshaus] na podstawie administracyjnej decyzji policji.

Minister Rudolf Amelunxen zapewne nie miał już odwagi dopisać, że w rozporządzeniu z 14 grudnia 1937 roku nie było mowy o „Domach Pracy”, tylko o kierowaniu potencjalnych przestępców do „Obozów Pracy” — a one w hitlerowskiej terminologii były jedną z form obozów koncentracyjnych — oraz że poważna część owych „potencjalnych przestępców” deportowana była tam za różne formy niechęci wobec III Rzeszy.

Czy to więc możliwe, by w kwietniu 1954 roku wysocy oficerowie zachodnioniemieckiej policji z kraju związkowego Nadrenia-Westfalia jednogłośnie żądali przywrócenia obozów koncentracyjnych jako instrumentu „dyscyplinowana" społeczeństwa? I żeby takie postulaty w całej powadze Krajowy Minister Prawa kierował do Federalnego Ministra Prawa w Bonn?

Pomysł nie był nowy. W październiku 1916 roku naczelnik wydziału kryminalnego policji w Dreźnie Robert Heindl po raz pierwszy w Niemczech wysunął pomysł stworzenia obozów koncentracyjnych dla „dawnych więźniów i recydywistów". W przekonaniu Heindla kryminalna działalność była bowiem udziałem niewielkiej grupy chronicznych przestępców, którą byłoby wskazane odizolować od reszty społeczeństwa. Taki krok miał być złotym środkiem na rzecz opanowania przestępczości w Niemczech.

W latach dwudziestych Robert Heindl został współpracownikiem Ministerstwa Spraw Wewnętrznych Rzeszy i jednym z najbardziej wpływowych specjalistów od prawa karnego. Konsekwentnie rozwijał swoją koncepcję. W programowej książce Der Berufverbrecher twierdził, że zdecydowana większość działań kryminalnych dokonywana jest przez mniej więcej 10 tysięcy zawodowych kryminalistów. Policja kryminalna jest w stanie te osoby bez trudu zidentyfikować. Gdyby mogła ona potencjalnych przestępców dożywotnio internować, przestępczość w Niemczech można by zredukować do nieistniejącego marginesu ${ }^{3}$.

Republika Weimarska była państwem w dużym stopniu demokratycznym. Takie metody działań prewencyjnych i nieograniczonej władzy policji nie znalazły społecznej akceptacji. Dlatego mimo wielkiego poparcia ze strony środowisk policyjnych koncepcja ta nie została wówczas wprowadzona w życie ${ }^{4}$.

Po 1933 roku głos społeczeństwa odgrywał jednak coraz mniejszą rolę, a rządy terroru były coraz brutalniejsze. Chociaż nie istniała ku temu jeszcze oficjalna podstawa prawna, policji kryminalnej udawało się coraz więcej niewygodnych czy podejrzanych osób deportować do obozów koncentracyjnych - byli tam

3 P. Wagner, Die Resozialisierung der NS Kriminalisten, [w:] Wandlungsprozesse in Westdeutschland. Belastung Integration, Liberalisierung 1945-1980, red. U. Herbert, Göttingen 2002, s. 181.

${ }^{4}$ Ibidem. 
odsyłani bez wyroku sądowego na czas nieokreślony, a to wobec wysokiej śmiertelności w obozach oznaczało dla bardzo wielu dożywotnie odosobnienie.

$\mathrm{Z}$ czasem działania policji otrzymały oficjalne ramy prawne w postaci rozporządzenia Pruskiego Ministra Spraw Wewnętrznych z 14 grudnia 1937 roku, którego przywrócenia domagali się oficerowie policji we wspomnianej uchwale z 1954 roku $^{5}$. Rozporządzenie z 14 grudnia 1937 roku dawało bowiem instancjom policyjnym całkowicie wolną rękę w decydowaniu o środkach stosowanych wobec osób podejrzanych z różnych powodów. Od tego momentu policyjne komisariaty zaczęły na coraz większą skalę deportować swoich stałych bywalców do obozów koncentracyjnych. Już w 1937 roku policja wysłała 2500 osób na dożywotnie odosobnienie. W roku 1938 liczba osób internowanych na polecenie policji wzrosła do 13 tysięcy. Od tej chwili deportowano każdą osobę, wobec której policja miała podejrzenia, że szkodzi porządkowi publicznemu' ${ }^{6}$.

Decyzje o deportacji do obozu koncentracyjnego na podstawie rozporządzenia z 14 grudnia 1937 roku stosowano wobec prostytutek, bezdomnych, Cyganów, homoseksualistów i wszystkich innych osób o poglądach niemieszczących się w hitlerowskiej ideologii. Z czasem prewencyjne działania na rzecz zapobiegania przestępczości o charakterze kryminalnym zeszły na drugi plan. Rozporządzenie z 14 grudnia 1937 roku stało się jednym z najważniejszych instrumentów politycznego terroru - i jednocześnie dokładnym przeciwieństwem tego, czym było w pierwotnych założeniach. W obozach koncentracyjnych często to kryminaliści byli oprawcami politycznych więźniów, a rozporządzenie z 14 grudnia 1937 roku stało się instrumentem niekontrolowanego zastraszania społeczeństwa.

$\mathrm{Z}$ czasem policja deportowała coraz więcej ludzi do obozów koncentracyjnych z coraz banalniejszych powodów. W 1944 roku wystarczyła kradzież kury, by zostać uznanym za zbrodniarza i zostać dożywotnio deportowanym. Do obozów koncentracyjnych odsyłano bezdomnych po nalotach bombowych, którzy w nowej sytuacji nie potrafili się psychicznie odnaleźć; trafiały tam niezamężne kobiety, które nie podejmowały stałej pracy, czy takie, które podejrzewano o seksualne kontakty z robotnikami przymusowymi; do obozów koncentracyjnych policja wysyłała zarówno niezdyscyplinowanych robotników przymusowych, jak i czarnorynkowych handlarzy. Wielka liczba osób deportowanych do obozów koncentracyjnych zginęła. Policjanci podejmujący decyzje o deportacji doskonale wiedzieli, jaki tych ludzi czeka los. O śmierci każdego z nich byli najczęściej informowani ${ }^{7}$.

Nie miejsce tu, żeby mówić o dramacie ludzi z różnych powodów zamkniętych w obozach koncentracyjnych. Napisano na ten temat dostatecznie dużo. Ich więźniowie żyli nadzieją, że po upadku III Rzeszy ich oprawcy zostaną należycie

5 Rozporządzenie przedrukowano w: ,, Gemeinschaftsfremde”. Quellen zur Verfolgung von „Asozialen” 1933-1945, red. W. Ayaß, Koblenz 1998, dokument nr 50, s. 217.

${ }^{6}$ P. Wagner, op. cit., s. 182.

7 Ibidem, s. 183. 
ukarani — po 1945 roku mieli być jednak dalece rozczarowani. Złożyło się na to wiele przyczyn.

Przede wszystkim propaganda III Rzeszy pozostawiła po sobie głębokie ślady. Wmówiła ona niemieckiemu społeczeństwu, że osoby umieszczane w obozach koncentracyjnych rzeczywiście działały na szkodę państwa i w ten sposób pośrednio przyczyniły się wojennej klęski. Z tego też względu w społeczeństwie niemieckim większość osób ukaranych przez policję kryminalną III Rzeszy była po 1945 roku postrzegana jako przestępcy. Utrzymywało się społeczne przekonanie, że skoro trafili do obozów koncentracyjnych, to rzeczywiście byli winni zarzucanych im przestępstw ${ }^{8}$.

Po wojnie policjanci wydziałów kryminalnych mieli więcej szczęścia, niż sami się spodziewali. Nikt nie interesował się zbrodniami popełnionymi na Niemcach, których władze III Rzeszy uznały za winnych. Aliantom chodziło przede wszystkim o ukaranie osób, które dopuściły się morderstw na ludności innych państw ${ }^{9}$. Poważnym obciążeniem policjantów był co prawda fakt, że z czasem policję kryminalną połączono z gestapo - większość funkcjonariuszy była jednocześnie członkami SS ${ }^{10}$. Dawni policjanci kryminalni zapewniali jednak, że szarże SS zostały im nadane wbrew ich woli. Twierdzili również, że o warunkach panujących w obozach koncentracyjnych nie mieli pojęcia, a tym bardziej że ginęli w nich ludzie ${ }^{11}$.

Począwszy od 1946 roku, większości dawnych funkcjonariuszy udał się szybki powrót do nowej zachodnioniemieckiej policji ${ }^{12}$. Należeli w końcu do młodego pokolenia hitlerowskich aktywistów, którzy ze szczególnym zaangażowaniem pilnowali interesów III Rzeszy ${ }^{13}$. Powrotowi hitlerowskich funkcjonariuszy sprzyjała atmosfera tamtych czasów. Niemiecki Bundestag 11 maja 1951 roku uchwalił przepisy wykonawcze do artykułu 131 niemieckiej Ustawy Zasadniczej. Umożliwiły one wszystkim rehabilitowanym przez komisje weryfikacyjne zbrodniarzom powrót na stanowiska tej samej rangi, jakie zajmowali przed 1945 rokiem, a nawet tworzyły mechanizmy, dzięki którym dawni hitlerowscy zbrodniarze mieli pierwszeństwo $\mathrm{w}$ ich otrzymaniu ${ }^{14}$.

${ }^{8}$ D. Garbe, Erinnerungsverweigerung und ,, Vergangenheitsbewältigung”: Der Umgang mit dem Nationalsozialismus in der früheren Bundesrepublik, [w:] Modernisierung im Wiederaufbau. Die westdeutsche Gesellschaft der 50 Jahre, red. A. Schildt, A. Sywottek, Bonn 1993, s. 711. Temu problemowi poświęcona jest po części książka S. Fikus, Trudny spadek dysydentów III Rzeszy w Republice Federalnej Niemiec, Warszawa 2013.

9 A. Weinke, Alliierter Angriff auf die nationale Souveränität? Die Strafverfolgung von Kriegsund NS Verbrecher in der Bundesrepublik, der DDR und Osterreich, [w:] Transnationale Vergangenheitspolitik. Der Umgang mit dem deutschen Kriegsverbrechen in Europa nach dem Zweiten Weltkrieg, red. N. Frei, Göttingen 2005, s. 45.

10 P. Wagner, Die Resozialisierung..., s. 184.

11 Ibidem, s. 195.

12 Ibidem, s. 184.

13 Ibidem, s. 180.

14 Bundesgesetzblatt (BGBl) 1951, nr 22, s. 307. 
Punktem wyjścia uchwalenia aktu prawnego z 11 maja 1951 roku było przekonanie, że III Rzesza była normalnym państwem, którego regulacji prawnych nie da się podważyć. Zakwestionowanie ich legalności prowadziłoby natomiast do całkowitego chaosu — dla przykładu musiałoby spowodować anulowanie wszystkich zawartych w tym czasie małżeństw. Konsekwencją podważenia legalności ustroju musiałoby być również anulowanie całego orzecznictwa w sprawie wypadków drogowych z okresu III Rzeszy ${ }^{15}$. Ustawa z 11 maja 1951 roku miała jednak kluczowe znaczenie przede wszystkim dla setek tysięcy dawnych aktywistów reżimu III Rzeszy. Jeżeli obywatele III Rzeszy poruszali się w ramach obowiązującego wówczas systemu prawnego, to działali prawidłowo. Skoro tortury podczas dochodzeń w sprawie przestępstw politycznych były w III Rzeszy legalne, to nikt nie może mieć pretensji do dawnych funkcjonariuszy gestapo o ich stosowanie. Funkcjonariusz nie mógł zatem z tego tytułu ponosić żadnych zawodowych, a tym bardziej karnych konsekwencji w Republice Federalnej. Od momentu uchwalenia wskazanej ustawy dalsza dyskusja na temat odpowiedzialności urzędników za zbrodnie III Rzeszy była więc bezprzedmiotowa ${ }^{16}$.

Dzięki tej ustawie do dawnej pracy policyjnej mogła zatem wrócić znakomita większość dawnych funkcjonariuszy SS i gestapo. Dotyczyło to również osób, które niegdyś w strukturach tego organu pełniły najbardziej eksponowane funkcje. O tym, kto i na jakie stanowisko mógł zostać przyjęty, najczęściej policjanci decydowali już samodzielnie. Sprawdzano przede wszystkim, czy dana osoba lojalnie zachowywała się wobec swoich kolegów po 1945 roku i czy aby kogoś nie zadenuncjowała. Zbrodnie wobec ludności cywilnej nie odgrywały żadnej roli ${ }^{17}$. $\mathrm{W}$ ten sposób do struktur nowego państwa powrócili dawni aktywiści III Rzeszy, którzy wcześniej odegrali decydującą rolę w realizacji jej zbrodniczych czynów - ludzie, którzy planowali i wykonywali masowe morderstwa i gwałty.

Drogę do niemieckiej policji znalazł dla przykładu Paul Werner. Ten sam, którego uważa się za autora i inicjatora wspomnianego na początku rozporządzenia Pruskiego Ministra Spraw Wewnętrznych z 14 grudnia 1937 roku, które dziesięć lat po wojnie wzbudziło ogromne uznanie policjantów w Düsseldorfie.

Paul Werner, członek SS od 1933 roku, był wcześniej zastępcą komendanta Urzędu Kryminalnego Rzeszy (Reichspolizeikriminalamt). Przypuszczalnie ponosił osobistą współodpowiedzialność za deportację dziesiątków tysięcy ludzi do obozów koncentracyjnych. Werner był zwolennikiem koncepcji zakładającej, że skłonności kryminalne mają charakter dziedziczny. Uważał, że kryminaliści byli genetycznie predestynowani do zbrodni i dlatego społecznie niebezpieczni. Dlatego też był chociażby zwolennikiem sterylizacji młodocianych przestępców.

15 H. Weinkauff, Die Militäropposition gegen Hitler und das Widerstandsrecht. Probleme des Militärischen Widerstandes gegen Hitler, Bonn 1954, s. 10.

16 J. Perels, Entsorgung der NS-Herrschaft? Konflikten im Umgang mit dem Hitler-Regime, Hannover 2004, s. 142.

17 P. Wagner, Die Resozialisierung..., s. 191. 
Podejrzewano go o udział w programie eutanazji chorych, a także zbrodnie na obywatelach polskich. Po powstaniu landu Badenii-Wirtembergii (Baden-Württenberg) Werner znalazł zatrudnienie w tamtejszym Ministerstwie Spraw Wewnętrznych. Tam też w kwietniu 1954 roku powierzono mu funkcję dyrektora rządowego (Regierungsdirektor) $)^{18}$.

Do policji wrócił również Theo Saevecke — 2 stycznia 1952 roku przyjęto go na stanowisko komisarza policji (Kriminalkommissar). Saevecke jako komendant policji bezpieczeństwa SS (SD Führer) w latach 1942/1943 zajmował się poszukiwaniami Żydów w Tunezji. Później w latach 1943/1944 koordynował deportacje Żydów z Mediolanu do obozów koncentracyjnych i wydawał rozkazy rozstrzeliwania zakładników. $Z$ tego też powodu już po wojnie uruchomiono przeciwko niemu dyscyplinarne postępowanie, które całkowicie oczyściło go z zarzutów ${ }^{19}$.

Do elity powojennych oficerów niemieckiej policji kryminalnej należał także Walter Zirpins, który w czasie wojny zdobył sławę dzięki rabowaniu majątków Żydów deportowanych do obozów koncentracyjnych. W 1941 roku był naczelnikiem policji kryminalnej w okupowanej Łodzi. Tam specjalizował się w wyszukiwaniu majątków, które ukrywali ludzie zagrożeni deportacją. W tym czasie Zirpins publikował w czasopiśmie „Kriminalistik”, w którym opisywał swoje łódzkie doświadczenia. W jego odczuciu getto było „zbieraniną kryminalistów, szmuglerów i oszustów", mieszkańcy getta najczęściej mieli płaskostopie (Platfuss), ale — jak pisał - „Żydzi też nie mieszkali w getcie w specjalnie komfortowych i luksusowych warunkach" ${ }^{20}$. Walter Ziprins z czasem został szefem wydziału kryminalnego policji w kraju związkowym Dolnej Saksonii (Nieder(sachsen $)^{21}$.

18 D. Stange, I. Wirth, Paul Werner (1900-1970). Stellvertretender Amtschef im Reichssicherheitshauptamt, „Zeitschrift für Geschichtswissenschaft” 2013, nr 7-8, s. 621-641; K. Seybold, Paul Werner: Großmeister der Vernichtungslager, in BRD-Zeiten Ministerialrat, [w:] Stuttgarter NS-Täter. Vom Mitläufer bis zum Massenmörder, red. H.G. Abmayer, Stuttgart 2009, s. 74-81. Pisano o nim również w gazecie „Der Spiegel” — zob. Revolver-Harry für Bonn, „Der Spiegel” 13.03.1951, s. 5.

19 Sicherungsgruppe, Erinnerung an Tunis, „Der Spiegel” 27.02.1963, s. 28; Saevecke. Der dritte von Links, „Der Spiegel” 12.06.1963, s. 23-26; Harster. Veroffiziert, „Der Spiegel” 18.09.1963, s. 52; P. Wagner, „Lippenbekenntnisse zum Rechtsstaat”, „Der Spiegel” 13.04.2011, s. 42; BAK B 106/21192, urzędowa korespondencja dotycząca Thea Saeveckego, cyt. za: P. Wagner, Die Resozialisierung..., s. 198.

20 W. Zirpins, Das Getto in Litzmannstadt, kriminalpolizeilich gesehen, „Kriminalistik” 1941, nr 9, s. 99.

21 Zob. H. Fischler, Neues zur Reichstagsbrandkontroverse. Wie Kriminalrat Dr. Walter Zirpins, Kronzeuge für die angebliche Alleintäterschaft Marinus van der Lubbes, dabei half, Fritz Tobias' Alleintäterthese zu widerlegen, [w:] Der Reichstagsbrand und der Prozess vor dem Reichsgericht, red. D. Deiseroth, Berlin 2005, s. 89-143; F. Liebert, „Die Dinge müssen zur Ruhe kommen, man muss einen Strich dadurch machen”. Politische ,Säuberung” in der niedersächsischen Kriminalpolizei nach 1945, [w:] Nachkriegspolizei. Sicherheit und Ordnung in Ost- und Westdeutschland 1945-1969, red. G. Fürnetz, H. Reinke, K. Weinhauer, Hamburg 2001, s. 71-104; R. Surman, D. Schröder, Vom NS-Goldräuber zum führenden Wirtschaftskriminologen der Bundesrepublik. Die Karriere des Dr. Walter Zirpins, [w:] Der lange Schatten der NS-Diktatur. Texte zur Debatte um 
Kolejnym ważnym etapem powrotu elit hitlerowskich do niemieckiej policji było utworzenie w 1951 roku Federalnego Urzędu Kryminalnego (Bundeskriminalamt, BKA ${ }^{22}$. Zbieżność utworzenia tego urzędu z uchwaleniem ustawy z 11 maja 1951 roku nie pozostała bez konsekwencji.

Do tego momentu czyniono jeszcze trudności w przywróceniu do służby hitlerowskich policjantów, którym stawiano poważne zarzuty. Od maja 1951 roku ograniczenia te przestały obowiązywać. Ustawa zawierająca przepisy wykonawcze do artykułu 131 niemieckiej Ustawy Zasadniczej otworzyła drogę do zawodowej kariery tym, którzy ze względu na swoją przeszłość i popełnione w czasie wojny niegodziwości nie mogli dotąd znaleźć zatrudnienia. Byli to przykładowo członkowie dawnych grup specjalnych (Einsatzgruppen), skompromitowani brutalnymi akcjami funkcjonariusze gestapo, żandarmerii wojskowej (Feldpolizei) czy pracownicy Urzędu Policji Kryminalnej Rzeszy (Reichskriminalpolizeiamt). Teraz funkcjonariusze ci nie starali się swojej hitlerowskiej przeszłości nawet ukrywać ${ }^{23}$.

W 1951 roku struktury policji krajowych były już jednak zbudowane, natomiast w trakcie organizacji znajdował się właśnie Federalny Urząd Kryminalny. Dlatego też wielu pozbawionych dotąd pracy hitlerowskich aktywistów zobaczyło tam dla siebie nowe perspektywy. Zatrudnieni tam wcześniej funkcjonariusze i w tym wypadku sami decydowali, kogo spośród dawnych towarzyszy mogą i chcą przyjąć w swoje szeregi. Liczyły się tylko dawne zawodowe i towarzyskie powiązania ${ }^{24}$. Nie może więc dziwić, że w latach pięćdziesiątych BKA był mocno w rękach dawnej kadry. Więcej niż połowa kierowników wydziałów była dawnymi wysokimi funkcjonariuszami $\mathrm{SS}^{25}$. Dawni aktywiści przeistoczyli BKA w silnie politycznie zorientowaną organizację. W niewzruszony sposób trwali przy dawnej ideologii i przekonaniach o zagrożeniach ze strony światowego żydostwa, inni widzieli swój życiowy cel w kontynuowaniu walki z homoseksualistami czy Romami ${ }^{26}$.

Raubgold und Entschädigung, red. R. Surman, D. Schröder, Hamburg-Münster 1999, s. 51-60; BAK B 106/21192, korespondencja służbowa na temat Waltera Ziprinsa, cyt. za: P. Wagner, Die Resozialisierung..., s. 192.

22 Federalny Urząd Kryminalny jest organizacją podporządkowaną Ministerstwu Sprawa Wewnętrznych RFN i ma główną siedzibę w Wiesbaden. Jest częścią sytemu policyjnego państwa. Celem działalności BKA jest ściąganie najcięższych przestępców na terenie Niemiec. Jego zadaniem jest koordynacja i kierowanie działaniami krajowych urzędów kryminalnych. BKA prowadzi również własne dochodzenia zarówno na terenie Niemiec, jak i na arenie międzynarodowej. W 1952 roku BKA został członkiem Interpolu.

23 P. Wagner, ,Lippenbekenntnisse zum Rechtsstaat”, s. 42.

24 P. Wagner, Die Resozialisierung..., s. 193.

25 Dla przykładu w 1958 roku na 47 kierowniczych stanowisk w BKA aż 33 urzędników wcześniej zdobyło wysoką rangę w SS; zob. BAK B 106/11395, zestawienie BKA, cyt. za: ibidem.

26 P. Wagner, ,Lippenbekenntnisse zum Rechtsstaat”, s. 42. 
Za przykład może posłużyć jeden z wyższych urzędników BKA — radca kryminalny (Kriminalrat) Josef Ochs. Ochs wcześniej był Obersturmführerem SS, koordynującym prześladowania Romów w III Rzeszy. Przy swoich poglądach po wojnie przypuszczalnie pozostał. W licznych konsultacji prowadzonych wówczas w ramach BKA namawiał do izolacji Romów i ich planowej marginalizacji ${ }^{27}$.

Natomiast wspomniany wcześniej Paul Werner, inicjator rozporządzenia z 14 grudnia 1937 roku, został kandydatem na stanowisko prezydenta BKA. Zaproponował go oficjalnie Minister Spraw Wewnętrznych Kraju Związkowego Badenia-Wittenberga; w uzasadnieniu jego kandydatury Minister zapewniał, że Paul Werner w latach 1933-1945 zachowywał się w sposób nienaganny (einwandfrei). Ostatecznie jednak jego kandydaturę odrzucono ${ }^{28}$.

Tymczasem jednym z prezydentów BKA został Paul Dickopf, również były oficer $\mathrm{SS}^{29}$. I on okazał się zdeklarowanym zwolennikiem przywrócenia obozów koncentracyjnych w powojennych Niemczech Zachodnich. Dickopf kilka miesięcy po wspomnianym na początku piśmie ministra dra Rudolfa Amelunxena przygotował w tej sprawie memorandum i również wystosował je do Federalnego Ministra Prawa Fritza Neumayera. Napisał tam między innymi:

Kontrola policyjna ma na celu zabieganie przestępstwom. Ma zapewnić resocjalizację osób sprawiających kłopoty i zapobiegać ewentualnym zbrodniom. Znakomitym rozwiązaniem tego problemu było rozporządzenie pruskiego ministra Spraw Wewnętrznych z 14.12.1937 roku [sic! — przypadek]. I dzisiaj główne elementy tego rozporządzenia można by zaakceptować i wprowadzić w życie [zu begrüssen]. [...] W obecnej formie kontrola policyjna jest całkowicie niewystarczająca. Nie jest w stanie skutecznie zapobiegać rozwojowi świata przestępczego. Dlatego też godna poparcia jest propozycja Ministra Spraw Wewnętrznych [dra Rudolfa Amelunxena - S.F.] Kraju Związkowego Nadrenia-Westfalia dotycząca przywrócenia rozporządzenia z 14.12.1937 roku. Mogłaby się ono stać nowym fundamentem reorganizacji kontroli policyjnej i gwarancji publicznego bezpieczeństwa [...]. Sprawa ta była omawiana na naradzie kierowników krajowych wydziałów policji kryminalnej zorganizowanej przez BKA w dniach 26 i 27 sierpnia 1954 roku w Eckernförde. Propozycja przywrócenia rozporządzenia z 14.12.1937 roku znalazła ich pełne i nieograniczone poparcie. Kontrola policyjna oparta na zasadach określonych przez rozporządzenie Pruskiego Ministra Spraw Wewnętrznych z 14.12.1937 znakomicie się w przeszłości sprawdziła [...]. Chociaż należy tu podkreślić, że środki zapobiegawcze stosowane powinny być wobec osób, wobec których takie instrumenty są konieczne. Osoby takie powinny być kierowane do obozów odosobnienia. Nie możemy po-

27 A. Stephan, „,Der Begriff Sonderbehandlung... war mir damals unbekannt”. Dr. Josef Ochs (1905-1987), ein ,Zigeunerexperte” mit Erinnerungslücken, [w:] I. Baumann et al., Schatten der Vergangenheit. Das BKA und seine Gründungsgeneration in der frühen Bundesrepublik, Köln 2011, s. 318.

28 BAK B 106/21192, wewnętrzna ministerialna korespondencja dotycząca kwestii oceny działalności Paula Wernera w III Rzeszy, cyt. za: P. Wagner, Die Resozialisierung..., s. 191.

29 P. Wagner, ,Lippenbekenntnisse zum Rechtsstaat”, s. 42; zob. także D. Schenk, Die braunen Wurzeln des BKA, Frankfurt am Main 2003; BAK N 1265/69, cyt. za: P. Wagner, Die Resozialisierung..., s. 188. 
stulować ich nazwania jak kiedyś. Ale można by rozważyć stworzenie instytucji, które można by współcześnie określić „Domami Pracy” [Arbeitshaus $]^{30}$.

Mimo tak zdecydowanego poparcia Paula Dickopfa koncepcja odnowienia mocy prawnej rozporządzeniu z 14 grudnia 1937 roku nie znalazła poparcia ministerialnych urzędników w Bonn ani ewentualnej większości parlamentarnej. Dyskusja na temat przywrócenia obozów koncentracyjnych w Republice Federalnej toczyła się dalej i trwała jeszcze wiele lat ${ }^{31}$. Nie była ona jednak przypadkiem, tylko wynikiem świadomej polityki rządu zorientowanej na przywrócenie dawnych elit i zaangażowania ich $\mathrm{w}$ proces odbudowy państwa niemieckiego ${ }^{32}$.

\section{Bibliografia}

\section{Archiwalia}

Federalne Archiwum w Koblencji — Bundesarchiv Koblenz, Zespół/Bestand 106, Zbiór 15738.

Pismo kierownika Federalnego Urzędu Kryminalnego BKA Paula Dickopfa do Federalnego Ministra Spraw Wewnętrznych z 4 września 1954 roku o sygnaturze KI-43/00-7656/54.

Pismo Ministra Prawa Kraju Nadrenii-Westfalii (Nordrhein-Westfalen) dr. Rudolfa Amelunxena z 12 kwietnia 1954 roku o sygnaturze 4350-III A. 3.

\section{Źródła}

Der lange Schatten der NS-Diktatur. Texte zur Debatte um Raubgold und Entschädigung, red. R. Surman, D. Schröder, Hamburg-Münster 1999.

Przepisy wykonawcze do paragrafu 131 Ustawy Zasadniczej Republiki Federalnej Niemiec, Bundesgesetzblatt (BGBl) 1951, nr 22.

Rozporządzenie Pruskiego Ministra Spraw Wewnętrznych z 14 lutego 1937 roku, dokument przedrukowany w: ,, Gemeinschaftsfremde”. Quellen zur Verfolgung von „Asozialen” 1933-1945, red. W. Ayaß, Koblenz 1998, dokument nr 50.

30 BAK B 106/15738, pismo kierownika Federalnego Urzędu Kryminalnego Paula Dickopfa do Federalnego Ministra Spraw Wewnętrznych z 4 września 1954 roku, sygn. KI-43/00-7656/54.

31 Dla przykładu w kwietniu 1964 roku BKA z Wiesbaden zorganizował konferencję „Vorbeugende Verbrechensbekämpfung”. Wystąpił na niej dyrektor rządowy (Regierungskriminaldirektor) Herbert Schäfer z centrali BKA. W swoim referacie ubolewał nad ,niedobrą atmosferą”, jaką alianci stworzyli wokół zasady aresztowań w celu zapobiegania przestępstw oraz obozów koncentracyjnych. Nadużywanie deportacji do obozów koncentracyjnych zdyskredytowało tę formę zapobiegania przestępczości. Jednakże zdaniem Schäfera system ten się sprawdził i byłby wart powtórzenia; zob. P. Wagner, Die Resozialisierung..., s. 179. W końcu koncepcje obozów koncentracyjnych upadły na skutek sprzeciwu systemu prawniczego, który zazdrośnie strzegł swoich kompetencji w zakresie decydowania o ograniczeniu wolności poszczególnych osób; zob. ibidem, s. 209.

32 Zob. S. Fikus, op. cit., Warszawa 2013, s. 77-176. 


\section{Opracowania}

Fikus S., Trudny spadek dysydentów III Rzeszy w Republice Federalnej Niemiec, Warszawa 2013. Fischler H., Neues zur Reichstagsbrandkontroverse. Wie Kriminalrat Dr. Walter Zirpins, Kronzeuge für die angebliche Alleintäterschaft Marinus van der Lubbes, dabei half, Fritz Tobias'Alleintäterthese zu widerlegen, [w:] Der Reichstagsbrand und der Prozess vor dem Reichsgericht, red. D. Deiseroth, Berlin 2005, s. 89-143.

Garbe D., Erinnerungsverweigerung und , Vergangenheitsbewältigung”: Der Umgang mit dem Nationalsozialismus in der früheren Bundesrepublik, [w:] Modernisierung im Wiederaufbau. Die westdeutsche Gesellschaft der 50 Jahre, red. A. Schildt, A. Sywottek, Bonn 1993, s. 693-716.

Heindl R., Der Berufsverbrecher. Ein Beitrag zur Strafrechtsform, Berlin 1928.

Liebert F., „Die Dinge müssen zur Ruhe kommen, man muss einen Strich dadurch machen”. Politische ,,Säuberung” in der niedersächsischen Kriminalpolizei nach 1945, [w:] Nachkriegspolizei. Sicherheit und Ordnung in Ost- und Westdeutschland 1945-1969, red. G. Fürnetz, H. Reinke, K. Weinhauer, Hamburg 2001, s. 71-104.

Perels J., Entsorgung der NS-Herrschaft? Konflikten im Umgang mit dem Hitler-Regime, Hannover 2004.

Schenk D., Die braunen Wurzeln des BKA, Frankfurt am Main 2003.

Seybold K., Paul Werner: Großmeister der Vernichtungslager, in BRD-Zeiten Ministerialrat, [w:] Stuttgarter NS-Täter. Vom Mitläufer bis zum Massenmörder, red. H.G. Abmayer, Stuttgart 2009, s. 74-81.

Stange D., Wirth I., Paul Werner (1900-1970). Stellvertretender Amtschef im Reichssicherheitshauptamt, „Zeitschrift für Geschichtswissenschaft” 2013, nr 7-8, s. 621-641.

Stephan A., ,, Der Begriff Sonderbehandlung... war mir damals unbekannt”. Dr. Josef Ochs (19051987), ein ,Zigeunerexperte” mit Erinnerungslücken, [w:] I. Baumann, H. Reinke, A. Stephan, P. Wagner, Schatten der Vergangenheit. Das BKA und seine Gründungsgeneration in der frühen Bundesrepublik, Köln 2011, s. 313-322.

Surman R., Schröder D., Vom NS-Goldräuber zum führenden Wirtschaftskriminologen der Bundesrepublik. Die Karriere des Dr. Walter Zirpins, [w:] Der lange Schatten der NS-Diktatur. Texte zur Debatte um Raubgold und Entschädigung, red. R. Surman, D. Schröder, Hamburg-Münster 1999, s. 51-60.

Wagner P., Die Resozialisierung der NS Kriminalisten, [w:] Wandlungsprozesse in Westdeutschland. Belastung Integration, Liberalisierung 1945-1980, red. U. Herbert, Göttingen 2002.

Wagner P., Volksgemeinschaft ohne Verbrechen. Konzeption und Praxis der Kriminalpolizei in der Zeit der Weimarer Republik und des Nationalsozialismus, Hamburg 1996.

Weinkauff H., Die Militäropposition gegen Hitler und das Widerstandsrecht. Probleme des Militärischen Widerstandes gegen Hitler, Bonn 1954.

Weinke A., Alliierter Angriff auf die nationale Souveränität? Die Strafverfolgung von Kriegs- und NS Verbrecher in der Bundesrepublik, der DDR und Osterreich, [w:] Transnationale Vergangenheitspolitik. Der Umgang mit dem deutschen Kriegsverbrechen in Europa nach dem Zweiten Weltkrieg, red. N. Frei, Göttingen 2005, s. 45.

Zirpins W., Das Getto in Litzmannstadt, kriminalpolizeilich gesehen, „Kriminalistik” 1941, nr 9.

\section{Teksty publicystyczne}

Harster. Veroffiziert, „Der Spiegel” 18.09.1963.

Saevecke. Der dritte von Links, „Der Spiegel” 12.06.1963.

Sicherungsgruppe, Erinnerung an Tunis, „Der Spiegel” 27.02.1963.

Studia nad Autorytaryzmem i Totalitaryzmem 40, nr 4, 2018

(C) for this edition by CNS 
Revolver-Harry für Bonn, „Der Spiegel” 13.03.1951.

Wagner P., ,Lippenbekenntnisse zum Rechtsstaat”, „Der Spiegel” 13.04.2011.

\title{
CONCENTRATION CAMPS AS A MODERN FORM OF FIGHTING CRIME IN THE GERMAN FEDERAL REPUBLIC
}

\begin{abstract}
Summary
The problem of participation of the Nazi elites in the structures of the German Federal Republic is increasingly engaging for German historians. Popular, non-academic works also address the issue of joining the police force by former officials of the Third Reich. However, in the German texts it is consistently stressed that Nazi elites did not influence the social and political life of the German Federal Republic. Nevertheless, the debate on reintroducing concentration camps shows the high standing of national socialism ideology long after World War II.
\end{abstract}

Keywords: Nazi officials, prosecuting Nazi war criminals, concentration camps, criminal police, Gestapo, post-war Germany, Konrad Adenauer.

Sebastian Fikus

prof.sebastian.fikus@gmail.com 